\title{
TEMPAT RELAKSASI DI JALAN JAKSA, JAKARTA
}

\author{
Fransiscus Jason ${ }^{1)}$ \\ 1) Program Studi S1 Arsitektur, Fakultas Teknik, Universitas Tarumanagara, jhalim310197@gmail.com

\begin{abstract}
Abstrak
Menjalani kehidupan di kota yang besar dan padat, seperti Jakarta, terkadang dapat mempengaruhi kondisi fisik, perasaan serta mental dari masyarakatnya. Dengan persaingan ekonomi yang ketat, masyarakat semakin sibuk dengan segala rutinitas aktivitas yang dilakukannya untuk dapat memenuhi kehidupannya. Rutinitas kerja dan kepadatan penduduk yang berakibat kurangnya lahan kosong serta lahan hijau, secara psikis dapat menimbulkan kejenuhan, tingkat stres meningkat dan emosi yang tidak stabil. Stres tidak hanya berdampak secara langsung terhadap masyarakat namun juga berdampak terhadap lingkungan. Akibat dari tingkat stres yang tinggi dapat menyebabkan gangguan psikologis, fisiologis dan perilaku. Dengan menghadirkan sebuah karya arsitektur yang mengangkat tema third place sebagai sebuah wadah yang menyediakan sarana rekreasi, relaksasi dan penyembuhan mental masyarakat kota diharapkan dapat terjadi peningkatan kualitas hidup masyarakat secara fisik dan mental. Tema third place dalam hal ini difungsikan sebagai ruang temu (communal space) yang bersifat mengayomi dan mencakup seluruh lapisan masyarakat untuk saling bertemu dan bertukar pikiran, berbagi serta menjadi wadah rekreasional yang dipadukan dengan program kesehatan dan kebugaran bagi para pekerja maupun masyarakat. Dihadirkannya wadah rekreasi dan kesehatan ini dapat memberi manfaat bagi masyarakat untuk membantu meningkatkan kondisi fisik dan mental serta dapat menghilangkan kepenatan sehari-hari.
\end{abstract}

Kata kunci: communal space; ruang temu; rutinitas kerja; stres

\begin{abstract}
Life in a big and crowded city, like Jakarta, can sometimes affect the physical, emotional and mental conditions of the community. With intense economic competition, people are increasingly busy with all routine activities in order to be able to fulfill their lives. Work routines and population density resulting in a lack of vacant land and green land, can psychologically cause boredom, increased stress levels and emotional instability. Stress not only have a direct impact on society but also impacts on the environment. High level stress can cause psychological, physiological and behavioral disorders. Creating an architectural work that raises the theme of the third place as a container that provides a means of recreation, relaxation and mental healing, urban communities are expected to be able to improve the quality of life of people physically and mentally. The theme of the third place in this case functions as a meeting room (communal space) which is protective and includes all levels of society to meet and exchange ideas, share and be a place of recreation integrated with health and fitness programs for workers and the community. The presence of this recreation and health container can benefit the community to improve physical and mental conditions and can eliminate daily fatigue.
\end{abstract}

Keywords : communal space; intersection room; stress; work routine

\section{PENDAHULUAN}

Daerah Khusus Ibukota Jakarta yang kita kenal sebagai Ibukota Republik Indonesia terletak di Pulau Jawa diantara Provinsi Banten dan Provinsi Jawa Barat. Memiliki luas sebesar 664.01 km2 dengan jumlah penduduk sebanyak 10.374.235 jiwa. Jakarta menempati urutan pertama sebagai kota dengan kepadatan yang paling tinggi. Kota metropolitan yang penuh dengan 
kegemerlapan membuat ratusan ribu orang rela pergi ke Jakarta untuk suatu perubahan. Menjalani kehidupan di kota yang besar dan padat, seperti Jakarta terkadang dapat mempengaruhi perasaan serta mental dari para masyarakatnya. Dngan persaingan ekonomi yang ketat, masyarakat semakin sibuk dengan segala aktivitas untuk dapat memenuhi kebutuhannya.

Kehidupan perkotaan yang padat ini mau tidak mau juga mempengaruhi pola hidup masyarakat. Kegiatan bekerja menuntut masyarakat untuk bekerja lebih cepat dan keras. Beban pekerjaan serta rutinitas yang dilakukan setiap hari dapat mempengaruhi mental seseorang, dan hal tersebut menjadi salah satu akibat utama yang memberikan dampak yang buruk bagi kesehatan, baik fisik maupun pikiran mereka.

Secara fisik, kepadatan mengakibatkan minimnya tanah kosong sehingga ruang hijau semakin sedikit. Akibat lain adalah sulitnya menghirup udara segar akibat polusi kendaraan, produktivitas menurun, dan daya tahan tubuh melemah. Polusi udara sudah menjadi bagian dari keseharian bagi warga Jakarta. Tingginya tingkat kepadatan kota Jakarta sedikit banyak memberi dampak pada tingginya tingkat polusi itu sendiri. Secara psikis, kepadatan menimbulkan kejenuhan, stres meningkat dan emosi yang labil. Stres tidak hanya berdampak secara langsung terhadap masyarakat namun juga berdampak terhadap lingkungan. Akibat dari tingkat stres yang tinggi menyebabkan gangguan psikologis, fisiologis dan perilaku.

Setiap orang secara terus menerus akan menghadapi stres baik itu dari perubahan fisik, psikis, dan sosial, baik dari dalam maupun dari luar lingkungan. Jika hal tersebut tidak dapat dihadapi dengan seimbang maka tingkat stres akan meningkat (Mechanic, 1962). Seseorang yang menghadapi stres akan mengalami kondisi-kondisi yang tidak mengenakkan secara psikis seperti timbulnya rasa cemas, frustrasi, terancam, tak tenteram yang semuanya itu berdampak pada munculnya konflik dalam jiwa mereka dan konflik tersebut diekspresikan dalam bentuk kemarahan atau ekspresi-ekspresi lain yang dapat membuat orang tersebut merasa nyaman atau terlepas dari stres yang dihadapinya (Tarstasky, 1993). Saat ini penanganan stres hanya dilakukan pada tahapan medis, di mana penderita sudah terlanjur mengalami gangguan kejiwaan. Seharusnya diakukan tindakan pencegahan sehingga penderita gangguan jiwa akan menurun serta tingkat stres akan berkurang.

Dengan melihat masalah kepadatan pekerjaan dan aktivitas di Jakarta yang menimbulkan stres dan penurunan kebugaran maka diusulkan sebuah proyek Relaxation Place yang mewadahi aktivitas rekreasi, kesehatan dan kebugaran.

\section{KAJIAN LITERATUR \\ Third place}

Sosiolog Ray Oldenburg (1997) menciptakan ungkapan "Third place" dalam bukunya yang berjudul "The Great Good Place". "Third place" sebagai sub-judul buku yang diperluas untuk membantu memperjelas konsep dari sebuah: fafe, warung Kopi, toko buku, bar, salon, dan tempat nongkrong lainnya di titik utama dalam sebuah komunitas.

Menurut Oldenburg tempat pertama adalah tempat tinggal orang-orang yang tinggal bersama. Tempat kedua adalah tempat di mana kita bekerja dan tempat di mana kita menghabiskan sebagian besar waktu keseharian kita. "A Third place" adalah tempat publik yang menyelenggarakan pertemuan orang secara teratur, sukarela, dan informal. "A Third place" adalah tempat untuk bersantai dan memiliki kesempatan untuk mengetahui dan dikenal oleh orang lain dan tempat terjadinya pertukaran informasi dan komunikasi. Oldenburg mengidentifikasi delapan karakteristik yang dimiliki oleh "Third places":

\section{a. Neutral Ground}

Setiap orang bebas datang dan pergi. Tidak ada persyaratan waktu atau undangan yang diperlukan. Sebagian besar kehidupan kita di tempat pertama (home) dan tempat kedua (work) terstruktur, tetapi tidak demikian halnya di "Third place". 
b. Act as a Leveler

Setiap orang dari semua lapisan masyarakat berkumpul di "Third place". Tidak ada perbedaan status sosial atau ekonomi.

c. Conversation is the Main Activity

Komunikasi antar dua individu atau lebih itu bersifat hidup, menstimulasi, penuh warna, dan menarik.

d. Assessable and Accommodating

Mereka cenderung berlokasi di tempat yang nyaman, berada dalam jarak tempuh berjalan kaki dari rumah seseorang.

e. There are Regulars

Banyak pelanggan tetap di tempat tersebut. Tapi tidak seperti tempat lain, pendatang baru dapat disambut ke dalam grup tersebut.

f. Low Profile

Sebagai struktur fisik, "A Thrid Place" biasanya simple (polos) dan tidak mengedepankan penampilan.

g. Mood is Playful

Dengan hadirnya berbagai sektor makanan, minuman, permainan, dan percakapan, suasana menjadi ringan dan menyenangkan. Suasana hati mendorong orang untuk tinggal lebih lama dan kembali berulang kali ke tempat tersebut.

h. A Home Away From Home

Pada intinya "A Third place" adalah tempat di mana orang merasa seperti di rumah. Mereka merasa seperti mereka pantas dan nyaman untuk berada di sana, dan biasanya memiliki rasa kepemilikan terhadap tempat tersebut.

\section{Definisi Pusat Relaksasi}

Menurut KBBI (2016), relaksasi [re·lak·sa·si] berarti pengenduran, pemanjangan (tentang otot). Sedangkan menurut Hakim (2004: 41), relaksasi merupakan suatu proses pembebasan diri dari segala macam bentuk ketegangan otot maupun pikiran senetral mungkin atau tidak memikirkan apapun.

Pendapat lain juga dikemukakan oleh Thantawy (1997: 67) "relaksasi adalah teknik mengatasi kekhawatiran/kecemasan atau stres melalui pengendoran otot-otot dan syaraf, itu terjadi atau bersumber pada obyek-obyek tertentu". Relaksasi merupakan suatu kondisi istirahat pada aspek fisik dan mental manusia, sementara aspek spirit tetap aktif bekerja. Dalam keadaan relaksasi, seluruh tubuh dalam keadaan homeostatis atau seimbang, dalam keadaan tenang tapi tidak tertidur, dan seluruh otot-otot dalam keadaan rileks dengan posisi tubuh yang nyaman.

Menurut orang awam relaksasi sering kali diartikan dengan rileks, yaitu suatu tindakan yang digunakan untuk melepas ketegangan atau kelelahan. Misalnya olahraga, menonton acara televisi, rekreasi ke tempat-tempat wisata dan menyalurkan hobi yang dimiliki. Untuk menghindari kerancuan dalam pemahaman arti relaksasi, maka dibawah ini akan membahas teori-teori yang berkaitan dengan relaksasi, meliputi pengertian, metode dasar, manfaat, jenisjenis, dan prosedur umum pelaksanaan relaksasi.

Dari beberapa pengertian di atas, dapat disimpulkan bahwa Pusat Relaksasi adalah suatu fasilitas kesehatan dan kebugaran yang menyediakan tempat/wadah untuk berbagai jenis relaksasi.

\section{Definisi Relaksasi}

Relaksasi adalah teknik yang dapat digunakan semua orang untuk menciptakan mekanisme batin dalam diri seseorang dengan membentuk pribadi yang baik, menghilangkan berbagai bentuk pikiran yang kacau akibat ketidak berdayaan seseorang dalam mengendalikan ego yang dimilikinya, mempermudah seseorang mengontrol diri, menyelamatkan jiwa dan memberikan kesehatan bagi tubuh. 


\section{Metode Dasar Relaksasi}

Metode dasar relaksasi adalah suatu proses melawan efek otonomis yang menyertai relaksasi dengan kecemasan dan ketegangan sehingga akan menimbulkan counter conditioning atau penghilangan.

\section{Manfaat Relaksasi}

Terdapat beberapa manfaat dari penggunaan Teknik relaksasi menurut Burn (dikutip oleh Beech dkk, 1982) ada beberapa keuntungan yang diperoleh dari latihan relaksasi, antara lain:

- Relaksasi akan membuat individu lebih mampu menghindari reaksi yang berlebihan karena adanya stres

- Masalah-masalah yang berhubungan dengan stres seperti hipertensi, sakit kepala, insomnia dapat dikurangi atau diobati dengan relaksasi.

- Mengurangi tingkat kecemasan.

- Mengurangi kemungkinan gangguan yang berhubungan dengan stres dan mengontrol anticipatory anxiety sebelum situasi yang menimbulkan kecemasan, seperti pada pertemuan penting, wawancara dan sebagainya. Penelitian menunjukan bahwa perilaku tertentu dapat lebih sering terjadi selama periode stres, misalnya naiknya jumlah rokok yang dihisap, konsumsi alkohol, pemakaian obat-obatan, dan makanan yang berlebih-lebihan.

- Kelelahan, aktivitas mental dan atau latihan fisik yang tertunda dapat diatasi dengan menggunakan keterampilan relaksasi.

- Kesadaran diri tentang keadaan fisiologis seseorang dapat meningkat sebagai hasil dari relaksasi, sehingga memungkinkan individu untuk menggunakan keterampilan relaksasi untuk timbulnya rangsangan fisiologis.

- Relaksasi merupakan bantuan untuk menyembuhkan penyakit tertentu dalam operasi, seperti pada persalinan yang alami, relaksasi tidak hanya mengurangi kecemasan tetapi juga memudahkan pergerakan bayi melalui cervix.

- Konsekuensi fisiologis yang penting dari relaksasi adalah bahwa tingkat harga diri dan keyakinan diri individu meningkat sebagai hasil kontrol yang meningkat terhadap reaksi stress.

- Meningkatkan keefektifan bekerja. Keadaan relaksasi dapat meningkatkan kecepatan seseorang dalam melakukan kegiatan sehari-hari.

\section{METODE}

Metode perancangan yang digunakan melalui tiga tahapan proses, yaitu input, proses dan output. Input berupa berbagai data yang terkait dengan usulan proyek, baik dari program terkait sampai dengan kondisi lingkungan di sekitar tapak. Setelah berbagai data tersebut dimasukkan maka tahap berikutnya yang dilakukan adalah dengan menganalisis berbagai data yang telah tersedia sehingga menjadikannya sebagai sebuah sintesis dan pada akhirnya sintesis tersebut akan dikumpulkan menjadi sebuah output akhir. 


\section{Metode Konvensional}

\section{Studi Teori \\ - Teori Open Architecture dan Third place \\ - Teori dan program ruang Relaxation Center \\ - Studi definisi dan jenis-jenis Relaxation Center \\ - Peraturan pemerintah setempat}

Melakukan studi secara langsung terhadap kawasan serta lokasi tapak yang akan dibangun agar dapat mengetahui kondisi secara fisik maupun non-fisik yang ada di dalam maupun di sekitar tapak.

\section{Studi Kasus}

Melakukan studi terhadap berbagai bangunan yang memiliki fungsi serta tipologi yang sama maupun serupa dan mencoba mengambil serta menyesuaikan program-program serta bentuk gubahan ke dalam bangunan.

Analisa Data

Melakukan analisis dan sintesis terkait dengan segala data yang telah didapat sehingga dapat menghasilkan sebuah hasil kesimpulan yang dapat membantu ke dalam proses perancangan bangunan.

Gambar 1. Metode Konvensional

Sumber: Penulis, 2020

\section{Kerangka Pikir}

\section{PROSES PERANCANGAN ARSITEKTUR}

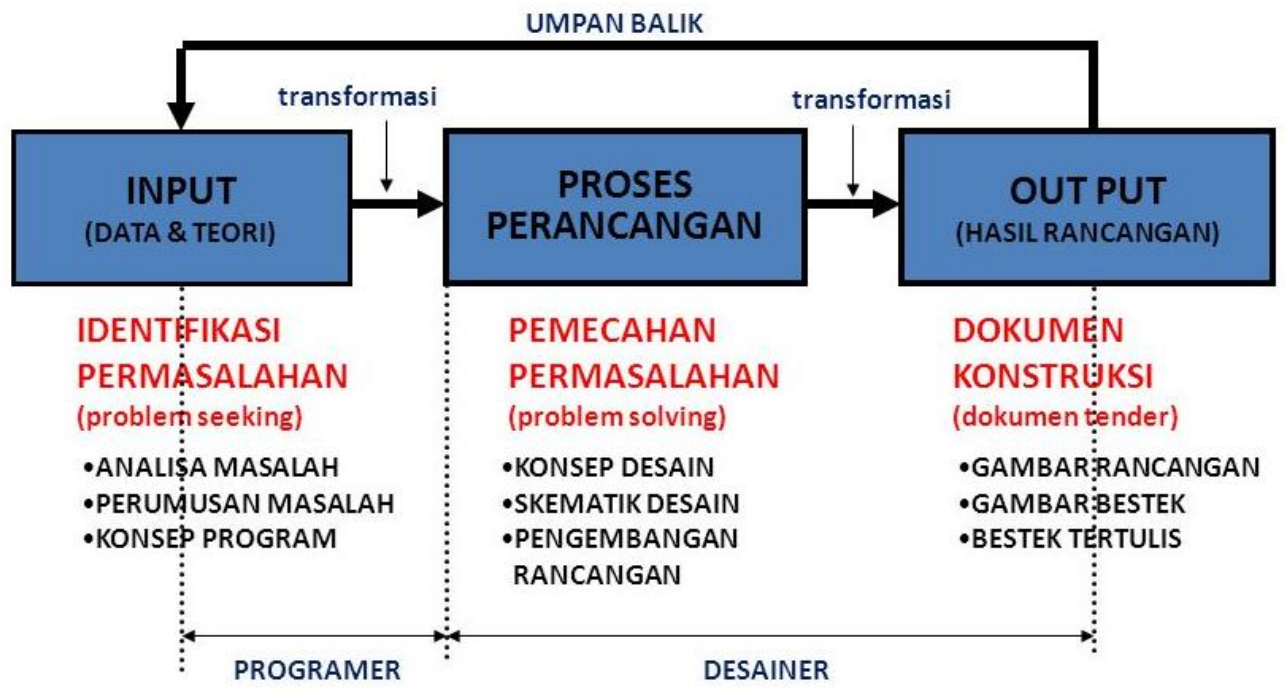

Gambar 2. Kerangka Pikir Metode Konvensional Sumber: Google, 2019

\section{Metode Perancangan Pattern Language}

Sebuah pattern language terdiri dari dua komposisi utama yang dirangkaikan sehingga bisa membentuk suatu bahasa yang pada akhirnya terpolakan menjadi pesan yang ingin 
dikomunikasikan dari tempat tersebut yaitu pattern of events dan pattern of space, dua keadaan ini saling membentuk satu sama lain (Alexander, 1979) sehingga keduanya menjadi kunci bagaimana suatu kualitas tanpa nama bisa terbentuk.

\section{Pattern of Events.}

Suatu events (peristiwa) bisa terbentuk karena terlibatnya beberapa faktor yaitu waktu, tempat, dan manusia. Komposisi dari faktor-faktor ini membentuk suatu keadaan yang unik yang dipengaruhi satu sama lain. Alexander dalam teori pattern of events nya menyatakan bahwa tiap tempat bisa memiliki karakter karena memiliki pola peristiwa yang selalu terjadi di sana (Alexander, 1979).

Dengan adanya pattern of events yang terjadi pada suatu tempat, kita tidak bisa memisahkan peristiwa yang terjadi terhadap tempat terjadinya peristiwa tersebut (Alexander, 1979) karena kedua hal ini memiliki ikatan satu sama lain yang menghasilkan karakternya tersendiri.

\section{Pattern of Space.}

Dalam pembentukan pattern language terdapat unsur pattern of events sangat dekat dengan konstribusi kegiatan manusia di dalamnya. Harus terdapat sebuah orientasi dan identifikasi yang baik terhadap manusia sehingga tercipta sebuah pattern of space yang baik yang berorientasi pada manusia tersebut yang akan menimbulkan suatu pola kegiatan yang membentuk dan dibentuk oleh ruang terjadi di sana. Namun pattern language juga bukan merupakan elemen konkrit yang selalu bisa kita sentuh seperti bata dan pintu, makna pattern language jauh lebih dalam dari pada itu dan substansial (Alexander, 1979)

Pertimbangan kegiatan yang terjadi di dalamnya yang akan membentuk pattern of events tidak hanya dipandang pada satu waktu saja tapi kita juga harus melihat keadaan kegiatan yang telah berlangsung dari masa lalu karena memang pada dasarnya sebuah arsitektur yang baik tidak pernah bisa berdiri sendiri, ia akan tetap mempertimbangkan keberadaan masa kini dan masa lalu (Alexander dan Rybcynski, 1986).

\section{DISKUSI DAN HASIL}

Proyek berupa sebuah sarana rekreasi yang dipadukan dengan program kesehatan dan kebugaran bagi para pekerja dan masyarakat yang bersifat menghibur untuk menurunkan tingkat stres akibat rutinitas keseharian serta kepadatan kota. Pendekatan yang digunakan kemudian diolah, dianalisis, dan digunakan sebagai acuan dasar dalam mendesain proyek. Dari hasil penelitian dapat dikatakan bahwa di sekitar kawasan site dikelilingi kawasan perkantoran dan perdagangan serta perhotelan dikarenakan kawasan Menteng merupakan salah satu kawasan wisata ternama di Jakarta. Mayoritas aktivitas yang ada di kawasan tersebut adalah bekerja, dikarenakan berada di daerah yang dekat dengan kawasan CBD (Central Business District). Kurangnya fasilitas kesehatan, kebugaran serta area hijau yang dapat menurunkan kondisi kesehatan dari segi fisik maupun mental yang mempengaruhi kinerja manusia dalam melakukan aktivitas. Oleh karena itu dibentuklah sebuah wadah rekreasi dan dipadukan dengan program kesehatan dan kebugaran.

Program yang disajikan pada proyek ini berupa sebuah relaxation place yang menggabungkan program rekreasi dengan kesehatan dan kebugaran. Konsep proyek dengan konsep bangunan meletakkan sebuah public plaza di bagian tengah yang menjadi penghubung utama yang mengkoneksikan pendatang dari ke empat sisi jalan di sekitar tapak. Wadah rekreasi dengan kesehatan dan kebugaran ini merupakan sebuah tempat bagi masyarakat untuk saling berkumpul, menenangkan diri, berinterkasi, serta bertukar pikiran. Perencanaan ini bertujuan sebagai sebuah wadah untuk menampung, mengembangkan, serta meningkatkan interaksi sosial antar individu dan menjadi wadah sarana kesehatan dan kebugaran untuk meningkatkan kualitas kehidupan masyarakat. 


\section{Profil Tapak Perancangan}

Jakarta pusat merupakan salah satu daerah Jakarta yang menjadi pusat perkantoran. Kawasan strategis yang berada di pusat kota serta dilengkapi dengan berbagai fasilitas trasportasi umum dan pedestrian.

Pada pemilihan tapak proyek, tapak yang dipilih adalah daerah Menteng, Jakarta Pusat dengan memperkirakan unsur-unsur penunjang yang menjadi kriteria pemilihan tapak yaitu berada di dekat tempat kerja/second place, berada di dekat pemukiman warga, transportasi publik dan jalur pedestrian. Tapak dapat dicapai oleh berbagai kendaraan umum seperti Transjakarta dan stasiun kereta api.

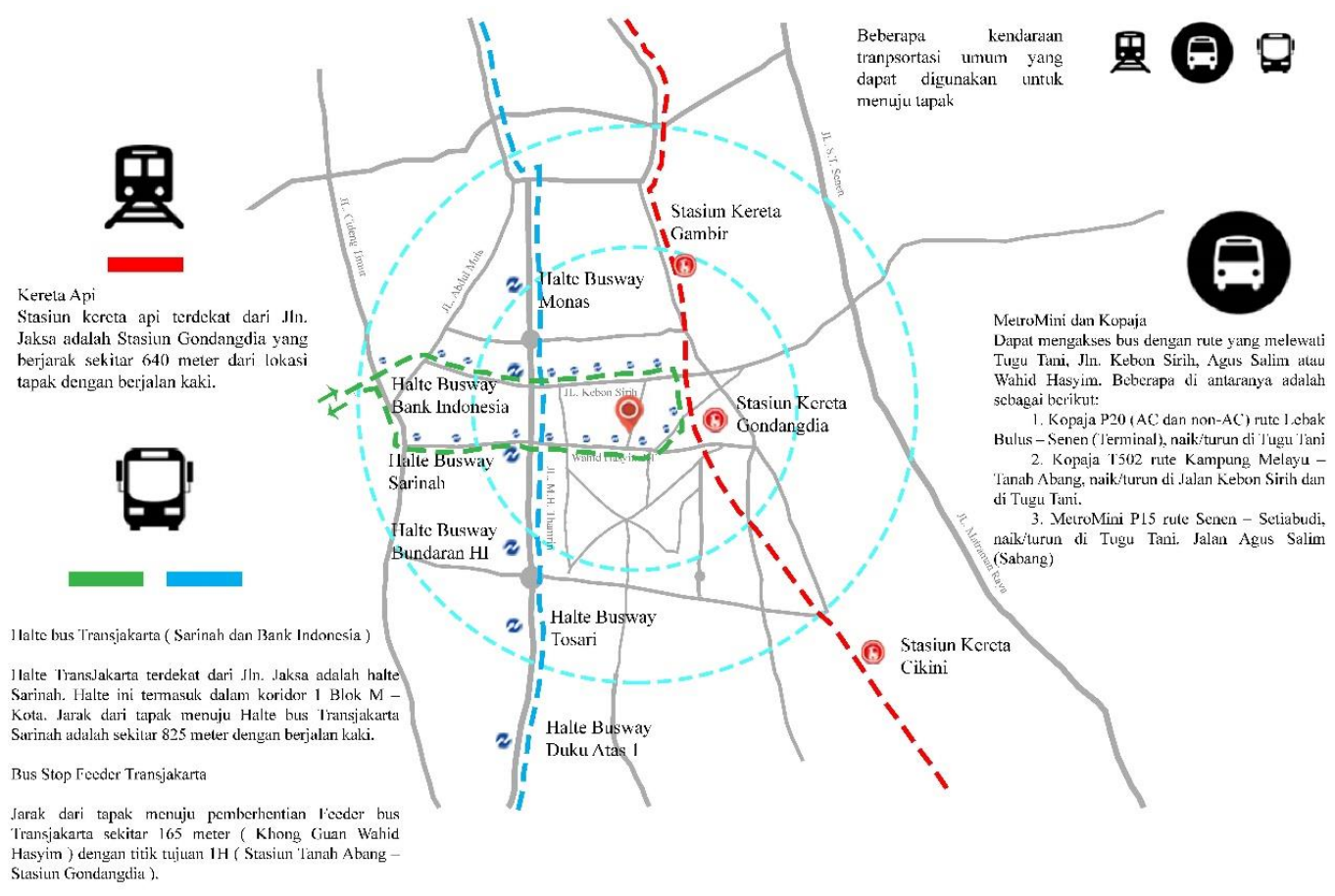

Gambar 3. Jarak Pencapaian Kendaraan Umum Sumber: Penulis, 2019

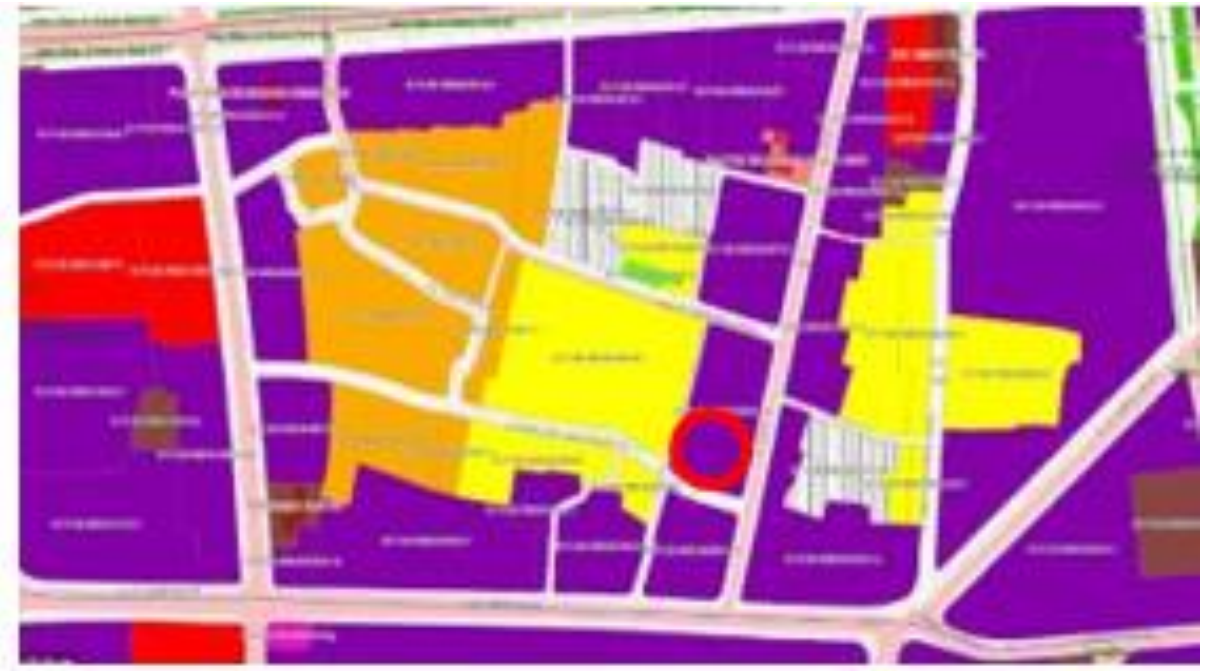

Gambar 4. Peta Zonasi Kawasan

Sumber: Jakartasatu, 2019 


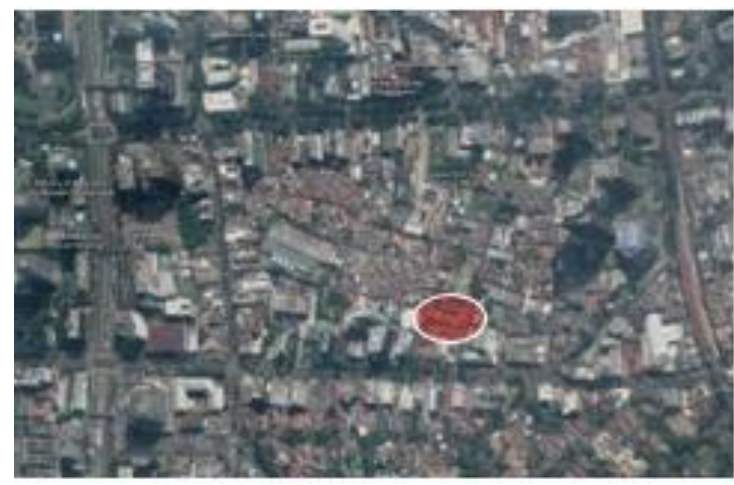

Gambar 5. Kondisi Tapak

Sumber: Google Map, 2019

Peruntukan

$\begin{array}{ll}\text { Lokasi } & \text { : Jalan Jaksa } \\ \text { Luas area } & : 3227 \mathrm{M}^{2} \\ \text { Zona } & : \text { Perkantoran, perdagangan dan jasa. } \\ \text { KDB } & : 60 \% \\ \text { Batas Tapak } & \\ \text { Utara } & \text { : Jalan Kebon Sirih Barat } 1 \\ \text { Selatan } & \text { : Jalan Kebon Sirih Barat } 1 \mathrm{Gg} .12 \\ \text { Timur } & \text { : Jalan Jaksa } \\ \text { Barat } & \text { : Jalan Kebon Sirih Barat } 1 \mathrm{Gg} .10\end{array}$

$\begin{array}{ll}\text { KTB } & : 55 \% \\ \text { KDH } & : 30 \% \\ \text { KB } & : 8 \\ \text { KLB } & : 2,4\end{array}$

$\mathrm{KLB} \quad: 2,4$

Kawasan Menteng merupakan tempat domisili banyak pejabat tinggi negara serta kedutaan besar negara-negara sahabat. Jalan Thamrin yang merupakan jantung kota Jakarta, terletak di bagian barat Kecamatan Menteng. Secara administratif, kawasan Menteng termasuk ke dalam kawasan "Segitiga Emas Jakarta". Kawasan ini dekat dengan beberapa fasilitas transportasi umum seperti halte busway (seperti Halte Busway Sarinah dan Bank Indonesia) dan beberapa stasiun kereta api (seperti Stasiun Gondangdia dan Stasiun Sudirman)

\section{Skema Desain}

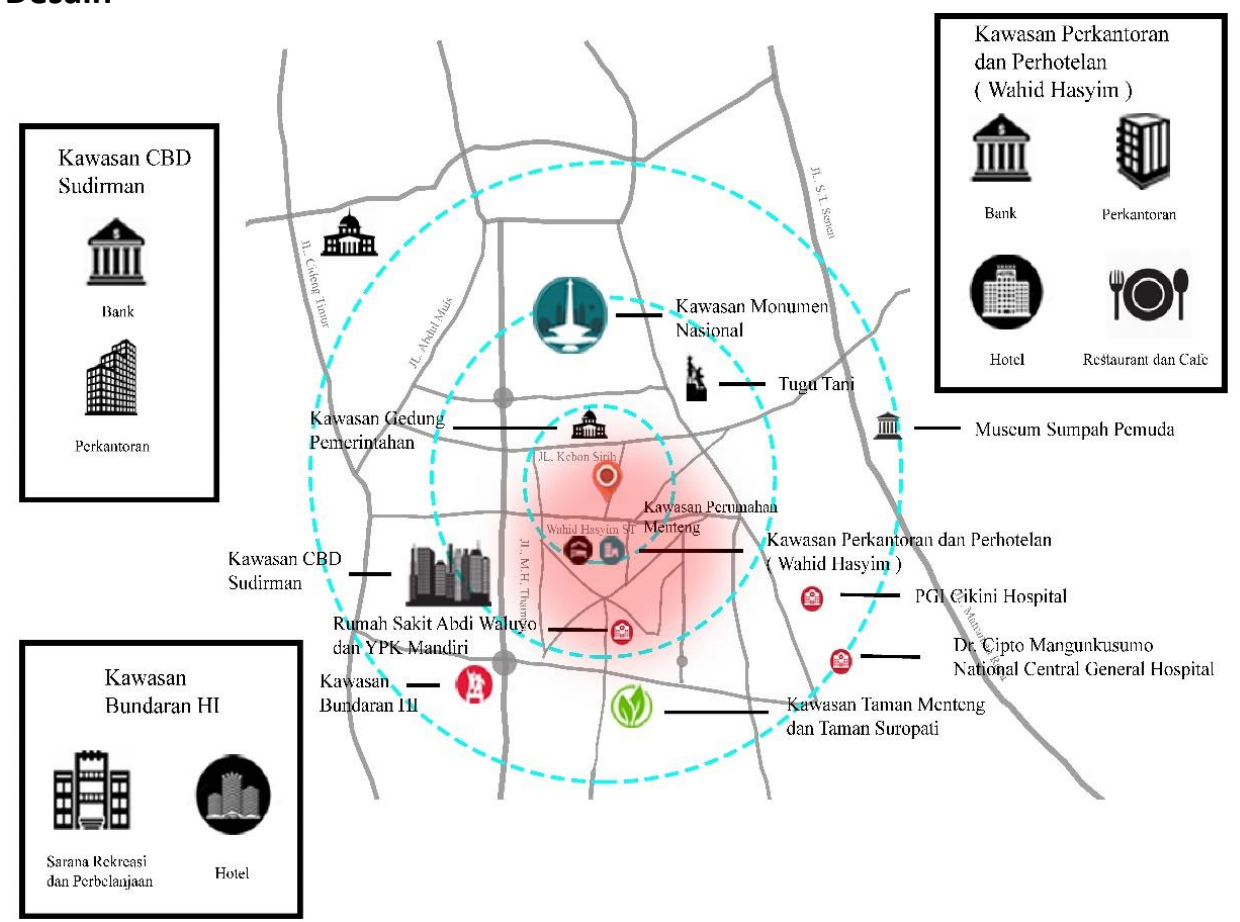

Gambar 6. Pemetaan Sarana dan Fasilitas Kawasan

Sumber: Penulis, 2019 


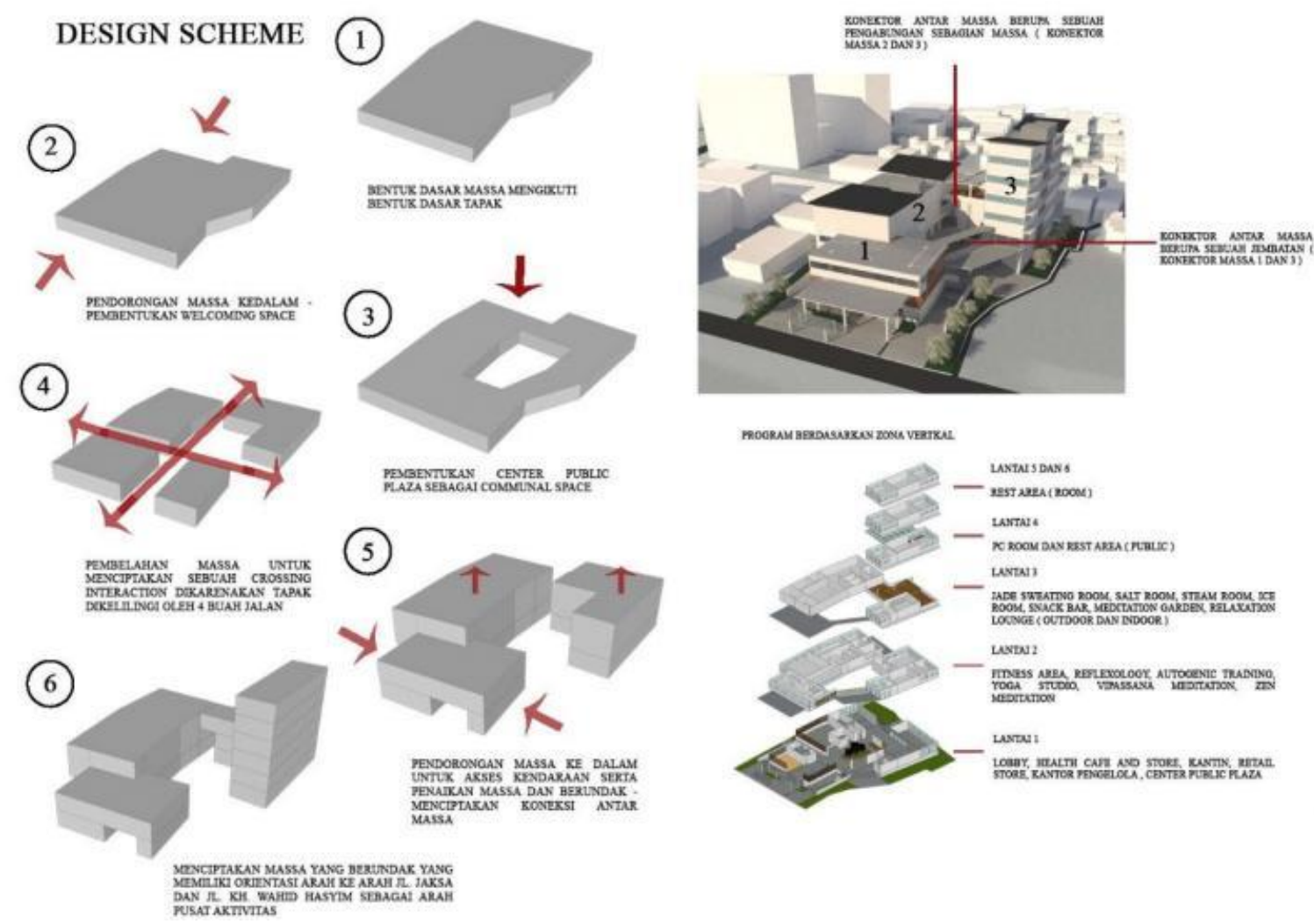

Gambar 7. Skema Desain

Sumber: Penulis, 2019

Pertama, Bentuk dasar massa mengikuti bentuk dasar tapak.

Kedua, dilakukan pendorongan massa kedalam (pembentukan welcoming space).

Ketiga, Pembentukan center public plaza sebagai communal space.

Keempat, Pembelahan massa untuk menciptakan sebuah crossing interaction dikarenakan tapak dikelilingi oleh 4 lajur jalan.

Kelima, Pendorongan massa ke dalam untuk akses kendaraan serta penaikan massa dan berundak (menciptakan koneksi antar massa).

Keenam, Menciptakan massa yang berundak yang memiliki orientasi ke arah Jalan Jaksa dan Jalan KH. Wahid Hasyim sebagai arah pusat aktivitas.

Bangunan wadah rekreasi dengan kesehaan dan kebugaran ini terdiri dari 2 massa bangunan dengan ketinggian 3 dan 6 lantai. Lantai 1 terdiri dari lobi, health café and store, musholla, public plaza, kantor pengelola dan retail. Lantai 2 terdiri atas fitness area, reflexology, autogenic training, yoga studio, vipassana meditation, zen meditation dan mini snack market. Lantai 3 terdiri dari dry spa (steam fomentation room, ice room, salt room, jade sweating room, snack bar), relaxation lounge (indoor), relaxation lounge (outdoor) dan meditation garden. Lantai 4 terdiri dari pc room dan rest area (public). Lantai 5 dan 6 terdiri dari rest area (room). 


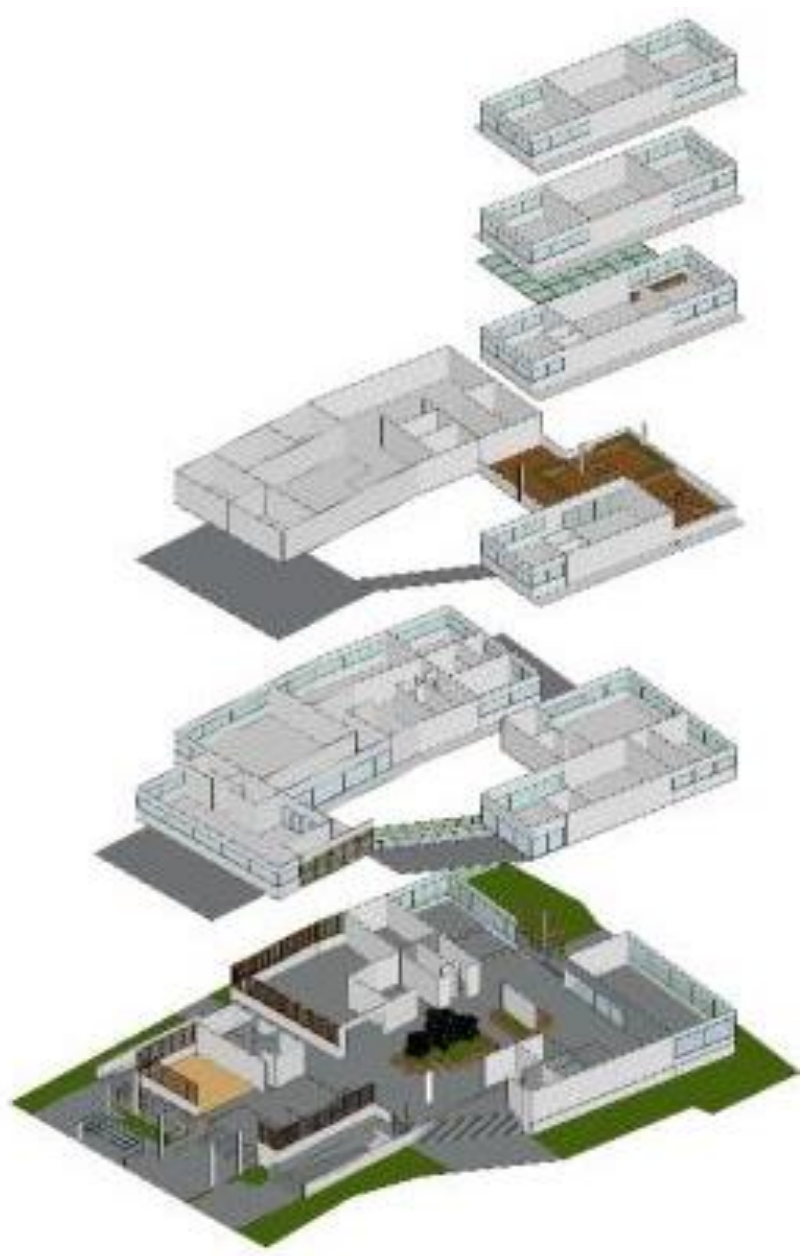

Gambar 8. Denah Exploded

Sumber: Penulis, 2019

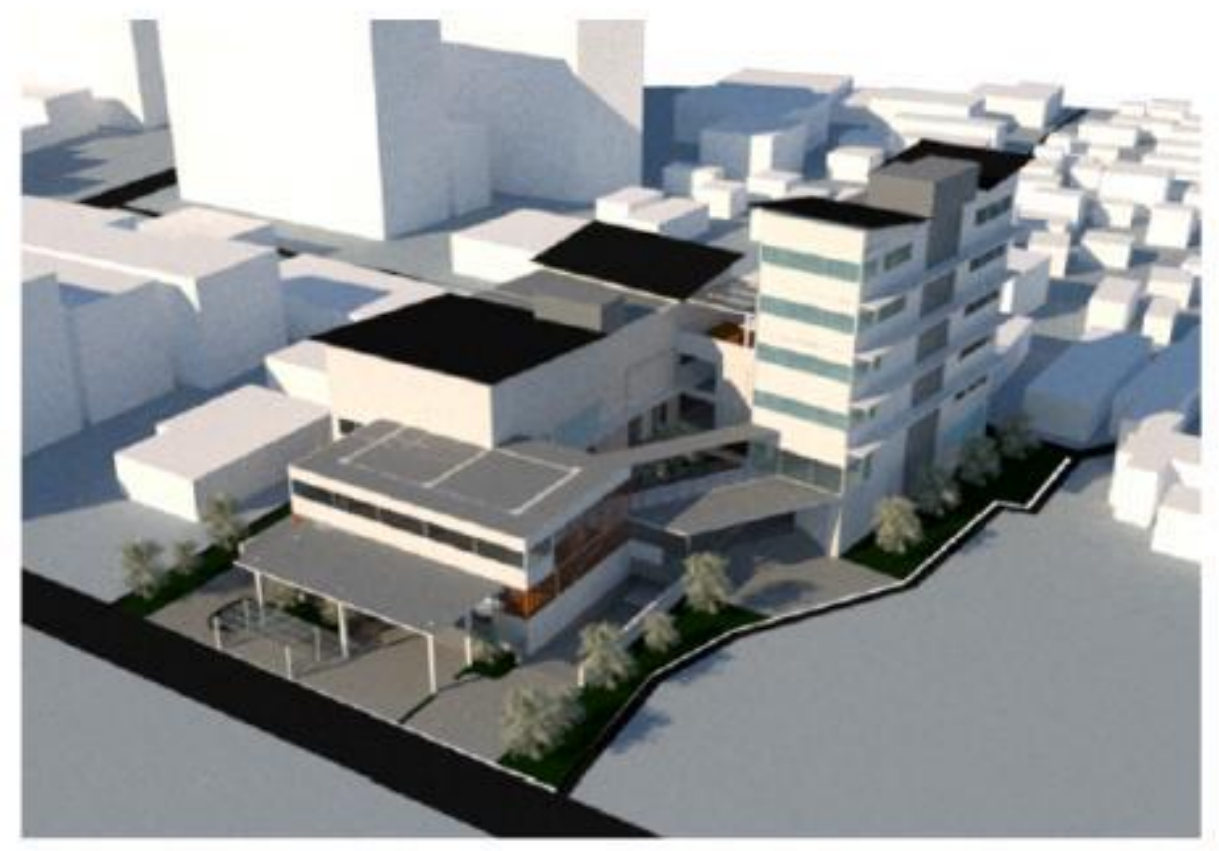

Gambar 9. Perspektif Bird Eye View

Sumber: Penulis, 2019 



Gambar 10. Perspektif Exterior Sumber: Penulis, 2019
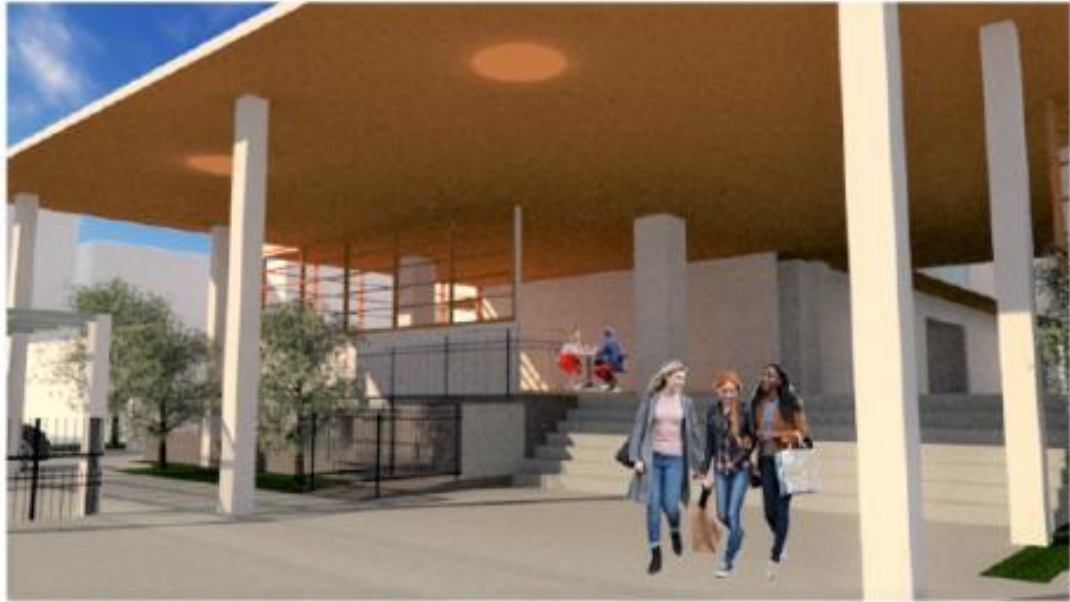

Gambar 11. Interior Lobby

Sumber: Penulis, 2019
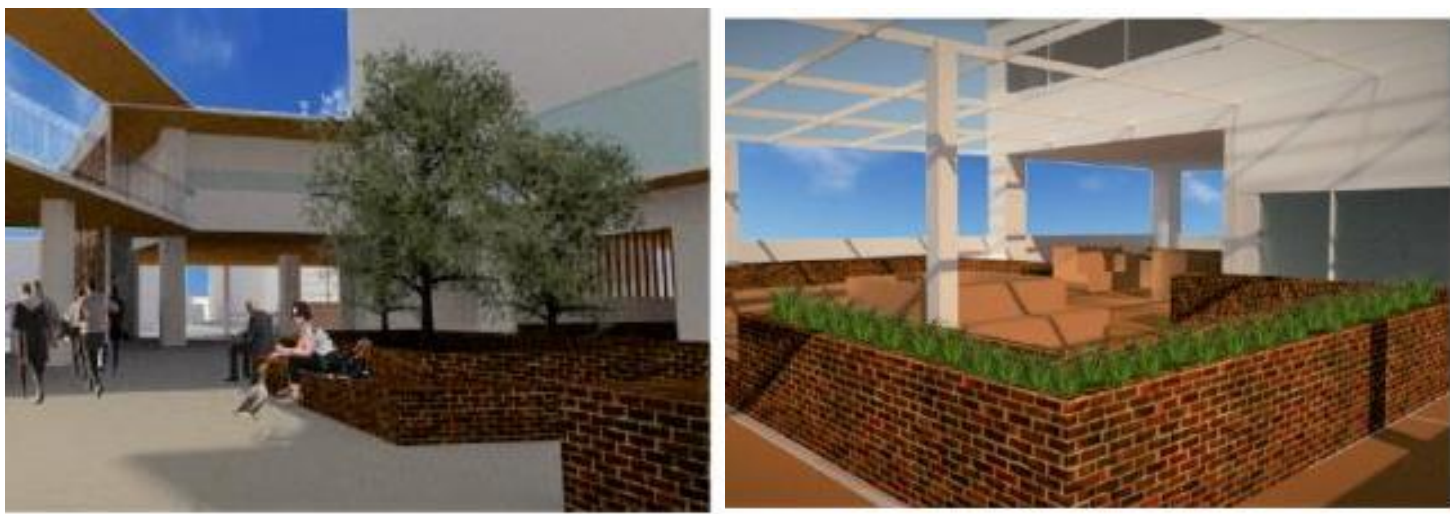

Gambar 12. Interior Public Plaza dan Meditation Garden

Sumber: Penulis, 2019

\section{KESIMPULAN DAN SARAN}

\section{Kesimpulan}

Perkembangan teknologi serta kesibukan rutin yang dilakukan setiap hari menimbulkan lahirnya sifat individualism pada diri seseorang serta mempengaruhi diri seseorang secara fisik maupun psikologisnya. Maka dari itulah the third place dalam hal ini menjadi jawaban dari permasalan tersebut. Fungsi proyek yang dirancang perlu memperhatikan kebutuhan kawasan serta kondisi fisik lingkungan sehingga perancangan proyek tersebut benar-benar dapat bermanfaat bagi masyarakat. 
Dalam hal ini perancangan proyek Relaxation Place berfungsi sebagai wadah untuk meningkatkan kesehatan serta kualitas hidup bagi masyarakat yang jenuh serta merasa lelah secara fisik dan psikologisnya akibat kepadatan serta rasa stres yang dialami dari pekerjaan serta rutinitas setiap harinya. Proyek Pelaxation Place ini diharapkan dapat berfungsi menjadi sebuah wadah untuk berkumpul dan saling berinteraksi antar individu (meningkatkan social life) serta tidak melupakan pentingnya kesehatan dan kebugaran dalam kehidupan sehari-hari.

Menciptakan sebuah wadah sarana rekreasi yang dipadukan dengan sarana kesehatan dengan tujuan untuk mengembangkan kembali kawasan yang secara perlahan semakin menurun menjadi pertimbangan utama dalam usulan proyek ini.

\section{Saran}

Diperlukan penambahan beberapa program-program baru agar dapat meningkatkan kualitas pelayanan kesehatan dan kebugaran, baik di dalam bangunan maupun di luar bangunan, serta menambahkan kapasitas luas ruang di setiap program untuk memperluas radius pelayanan.

\section{REFERENSI}

Alexander, C. (1979). Timeless Way of Building. New York: Oxford University Press

Beech, B. (1982). Relaxation and Psiko Therapy. Jakarta: Rineka Cipta

Felman, A. (diunduh 23 Juli 2019)., Why Stress Happens and How to Manage It, <https://www.medicalnewstoday.com/articles/145855.php\#what_is_stress>

Hakim, T. (2005). Mengatasi Gangguan Konsentrasi. Jakarta: Puspa Swara.

Mechanic, D. (1962). Students Under Stress: A Study in the Social Psychology of Adaptation. New York: The Free Press

Musradinur. (2016). Stres dan Cara Mengatasinya Dalam Perspektif Psikologi

Oldenburg, R. (1997). The Great Good Place. Amerika Serikat: Cambridge

Riadi, M. (diunduh 24 Juli 2019). Pengertian, Penyebab dab Akibat Stres Kerja. <https://www.kajianpustaka.com/2016/10/pengertian-penyebab-dan-akibat-streskerja.html>

Tartasky, D. S. (1993). Hardiness: Conceptual and Methodological Issues. Image, 25, 225-229.

Thantawy, R. (1997). Manajemen Bimbingan dan konseling, Jakarta: Pamator

Widhiastuti, H. (2002). Studi Meta-Analisis Tentang Hubungan Antara Stress Kerja dengan Prestasi Kerja

, (10 September 2019). "Panduan Tips Pergi Liburan Ke Jalan Jaksa". Pergimulu.com. 10 September 2019. <https://pergimulu.com/panduan-tips-pergi-liburan-ke-jalan-jaksa>

(18 Maret 2019) . "Stres". Alodokter.com. 15 Juli 2019. <https://www.alodokter.com/stres> 